\title{
Analysis of significant lean manufacturing elements through application of interpretive structural modeling approach in Indian industry
}

\author{
Rakesh Kumar $^{\mathbf{a}^{*}}$ and Vikas Kumar
}

${ }^{a}$ Research Scholar, Mechanical Engineering Department, YMCA University of Science and Technology, India ${ }^{b}$ Associate Professor, Mechanical Engineering Department, YMCA University of Science and Technology, India

\begin{tabular}{l}
\hline C H R O N I C L E \\
\hline Article history: \\
Received April 18, 2015 \\
Received in revised format May \\
10,2015 \\
Accepted June 252015 \\
Available online \\
July 32015 \\
\hline Keywords: \\
Lean manufacturing \\
Lean manufacturing elements \\
ISM \\
SSIM \\
Diagraph
\end{tabular}
A B S T R A C T

Lean Manufacturing is being adopted by many Indian industries based on its capability of improving manufacturing performance. Lean Manufacturing supports the concept of delivering the low cost and good quality product to customer by focusing on elimination of waste. Lean Manufacturing employs various elements which aspire to involve the employees to create a customer centric organization. This paper is an attempt to examine the significance of various lean manufacturing elements in Indian industries. Interpretive Structural Modeling (ISM) approach is used to examine their inter-relationship and ranking based on their driving power and dependence powers through development of diagraph and structural model in the Indian industry context.

(C) 2016 Growing Science Ltd. All rights reserved.

\section{Introduction}

Lean Manufacturing (LM) is a well-recognized manufacturing approach which emphasis on improving manufacturing efficiencies through identifying and removing waste from the manufacturing system. India is emerging as a focal point for global manufacturing and hence Indian industries are facing the heat of global competition. To stay alive in competitive environment, Indian industries need to reinforce their strengths and improve based on their weakness. LM has turn out to be a subject of the attention for Indian manufacturing companies based on its capability of improving competitiveness by reducing manufacturing lead time, improving product quality, reducing manufacturing costs, reducing material handling. It also creates an environment of delivering product with reduced delivery time, lower cost, reduced waste and improved customer satisfaction (Deif, 2012; Taj \& Morosan, 2011). Organizations which have implemented lean are able to work with reduced cost of manufacturing, lower inventories, reduced quality defects and making product available based on the customer requirement (Kumar \& Kumar, 2014). LM recommends the identification and segregation of value-adding and non-valueadding activities. A value adding activity is one for which customer is willing pay for (Nordin et al., 2010). Researchers have studied the different elements of lean in the context of Indian industry. The 
purpose of this study is to distinguish the correlation and ranking of various LM elements. An interrelationship is established among the different LM elements based on the impact of the interdependencies of the LM elements on each other. An ISM model is constructed to recognize the relationship among the LM elements. The aim of this paper is to identify

I. The relationship between the lean elements

II. Analysis of LM elements based on their deriving power and dependent power

III. Rank of hierarchy of the lean elements

IV. To provide guideline to Indian industry for focusing on elements with high impact to gain more benefits.

\section{Identification of LM Elements in Indian context}

India is rising as an international hub for manufacturing. So existence of multinational companies in India is growing on yearly basis. Therefore Indian manufacturing organizations are now facing global competition in Indian market itself and hence they are aggravated to take serious step forward to keep them competitive and one such step is LM implementation. The key purpose of LM is to improve utilization of resources and space more effectively consequently increasing more yield from their existing resources. Lean Manufacturing is put into practice to improve the competency through eliminating the waste and non-value adding activities from the manufacturing system. Waste can be present in the manufacturing system in many ways like overproduction, excess inventory, over processing, unnecessary transportation, defects, waiting and avoidable motion (Womack et al., 1990). After implementation of LM organizations are expected to have improved operational efficiencies, product quality and overall performance (Kumar \& Kumar, 2012). Manufacturing industries over the global have understood the implications of high inventories so they are rapidly shifting their manufacturing process from batch production to a new manufacturing approach with lesser inventories, called lean manufacturing (Kumar \& Kumar, 2012). Lean manufacturing is a manufacturing style which highlights the identification and elimination of all types of wastes from the processes making it more efficient (Mohan raj et al., 2011).

In a study conducted by Kumar and Kumar (2015) a two tailed t- test with a significance level of five percent was carried out to establish the significance of various LM elements. The hypothesis was developed that if the Lean manufacturing elements given in Table 1 are not significant for LM in Indian industry the null hypothesis $\left(\mathrm{H}_{0}\right)$ will be rejected and alternate hypothesis $\left(\mathrm{H}_{\mathrm{a} 1}\right)$ will be accepted.

It was observed that nine LM elements out of total 29 elements are significant lean manufacturing elements over other lean elements in Indian industry based on survey results. Followings are the observed significant LM elements:

I. Total Employee Involvement

II. Inventory reduction

III. Wastage identification

IV. Continuous improvement

V. Load leveling

VI. Small lot size

VII. Cycle time reduction

VIII. Lead time reduction

IX. Standardization 
Table 1

Significance of Lean manufacturing elements in Indian industry (adopted from Kumar \& Kumar, 2015)

\begin{tabular}{|c|c|c|c|c|c|c|c|c|c|c|c|}
\hline \multicolumn{11}{|c|}{ Low $\rightarrow$ High } & \\
\hline S.No. & LM elements & 1 & 2 & 3 & 4 & 5 & Mean & $\begin{array}{l}\text { Std. } \\
\text { dev. }\end{array}$ & t-value & Results & \\
\hline 1 & Inventory reduction & 0 & 1 & 13 & 23 & 22 & 4.119 & gf & 2.0807 & $\mathrm{H}_{\mathrm{o}}$ rejected & $\mathrm{H}_{\mathrm{a} 1}$ accepted \\
\hline 2 & Total Employee & 0 & 1 & 12 & 26 & 20 & 4.102 & 0.781 & 1.9943 & $\mathrm{H}_{\mathrm{o}}$ rejected & $\mathrm{H}_{\mathrm{a} 1}$ accepted \\
\hline 3 & Error proofing/poka-Yoke & 1 & 8 & 20 & 26 & 4 & 3.407 & 0.873 & -4.3282 & $\mathrm{H}_{\mathrm{o}}$ accepted & \\
\hline 4 & Set up reduction. & 0 & 3 & 15 & 25 & 16 & 3.915 & 0.857 & 0.1467 & $\mathrm{H}_{\mathrm{o}}$ accepted & \\
\hline 5 & Improve OEE. & 0 & 4 & 13 & 31 & 11 & 3.831 & 0.813 & -0.6463 & $\mathrm{H}_{\mathrm{o}}$ accepted & \\
\hline 6 & De-bottlenecking & 0 & 1 & 11 & 35 & 12 & 3.983 & 0.682 & 0.9478 & $\mathrm{H}_{\mathrm{o}}$ accepted & \\
\hline 7 & Line pace & 2 & 15 & 27 & 15 & 0 & 2.932 & 0.807 & -9.2064 & $\mathrm{H}_{\mathrm{o}}$ accepted & \\
\hline 8 & Wastage identification & 0 & 1 & 14 & 20 & 24 & 4.136 & 0.84 & 2.1647 & $\mathrm{H}_{\mathrm{o}}$ rejected & $\mathrm{H}_{\mathrm{a} 1}$ accepted \\
\hline 9 & Equipment uptime & 1 & 20 & 27 & 11 & 0 & 2.814 & 0.754 & -11.0606 & $\mathrm{H}_{\mathrm{o}}$ accepted & \\
\hline 10 & Quality at source. & 0 & 2 & 7 & 38 & 12 & 4.017 & 0.682 & 1.3295 & $\mathrm{H}_{\mathrm{o}}$ accepted & \\
\hline 11 & Takt Time working & 2 & 6 & 11 & 30 & 10 & 3.678 & 0.99 & -1.7136 & $\mathrm{H}_{\mathrm{o}}$ accepted & \\
\hline 12 & Small lot size & 0 & 0 & 9 & 31 & 19 & 4.169 & 0.673 & 3.0864 & $\mathrm{H}_{\mathrm{o}}$ rejected & $\mathrm{H}_{\mathrm{a} 1}$ accepted \\
\hline 13 & Continuous improvement & 0 & 1 & 9 & 29 & 20 & 4.153 & 0.738 & 2.6385 & $\mathrm{H}_{\mathrm{o}}$ rejected & $\mathrm{H}_{\mathrm{a} 1}$ accepted \\
\hline 14 & Good Housekeeping & 0 & 3 & 13 & 30 & 13 & 3.898 & 0.803 & -0.0056 & $\mathrm{H}_{\mathrm{o}}$ accepted & \\
\hline 15 & Manpower reduction & 0 & 1 & 9 & 37 & 12 & 4.017 & 0.656 & 1.3817 & $\mathrm{H}_{\mathrm{o}}$ accepted & \\
\hline 16 & Load leveling (Heijunka) & 0 & 2 & 7 & 33 & 17 & 4.102 & 0.736 & 2.1175 & $\mathrm{H}_{\mathrm{o}}$ rejected & $\mathrm{H}_{\mathrm{a} 1}$ accepted \\
\hline 17 & Reduced information & 0 & 11 & 10 & 24 & 14 & 3.695 & 1.038 & -1.5092 & $\mathrm{H}_{\mathrm{o}}$ accepted & \\
\hline 18 & Cycle time reduction & 0 & 3 & 5 & 34 & 17 & 4.102 & 0.759 & 2.0531 & $\mathrm{H}_{\mathrm{o}}$ rejected & $\mathrm{H}_{\mathrm{a} 1}$ accepted \\
\hline 19 & Quick changeovers & 0 & 3 & 10 & 27 & 19 & 4.051 & 0.839 & 1.3909 & $\mathrm{H}_{\mathrm{o}}$ accepted & \\
\hline 20 & Process control. & 0 & 4 & 9 & 34 & 12 & 3.915 & 0.794 & 0.1583 & $\mathrm{H}_{\mathrm{o}}$ accepted & \\
\hline 21 & Lead time reduction & 0 & 0 & 13 & 28 & 18 & 4.085 & 0.726 & 1.9662 & $\mathrm{H}_{\mathrm{o}}$ rejected & $\mathrm{H}_{\mathrm{a} 1}$ accepted \\
\hline 22 & Safe working & 0 & 2 & 12 & 28 & 17 & 4.017 & 0.799 & 1.1356 & $\mathrm{H}_{\mathrm{o}}$ accepted & \\
\hline 23 & Standardization. & 0 & 0 & 10 & 33 & 16 & 4.102 & 0.662 & 2.3545 & $\mathrm{H}_{\mathrm{o}}$ rejected & $\mathrm{H}_{\mathrm{a} 1}$ accepted \\
\hline 24 & Reduce variability. & 0 & 5 & 13 & 27 & 14 & 3.847 & 0.887 & -0.4454 & $\mathrm{H}_{\mathrm{o}}$ accepted & \\
\hline 25 & JIT deliveries & 0 & 1 & 10 & 32 & 16 & 4.068 & 0.716 & 1.8122 & $\mathrm{H}_{\mathrm{o}}$ accepted & \\
\hline 26 & Flexible manufacturing. & 0 & 0 & 11 & 33 & 15 & 4.068 & 0.666 & 1.948 & $\mathrm{H}_{\mathrm{o}}$ accepted & \\
\hline 27 & Layout improvement. & 2 & 4 & 10 & 34 & 9 & 3.746 & 0.921 & -1.2772 & $\mathrm{H}_{\mathrm{o}}$ accepted & \\
\hline 28 & Line Balancing & 0 & 4 & 10 & 28 & 17 & 3.983 & 0.861 & 0.7509 & $\mathrm{H}_{\mathrm{o}}$ accepted & \\
\hline 29 & Pull System & 0 & 2 & 14 & 18 & 25 & 4.119 & 0.892 & 1.8919 & $\mathrm{H}_{\mathrm{o}}$ accepted & \\
\hline
\end{tabular}

\section{Research methodology}

Interpretive Structural Modeling (ISM) technique is used for development of a Structural model for LM elements. The purpose of this study is to examine the relationships among the various significant LM elements and presenting a rank to LM elements in the Indian industries context. The LM elements are observed for their inter-relationship and ranks in terms of their driving power and dependence power. Reachability matrix is achieved to assign the rank to the elements. It is difficult to examine all twenty-nine element of LM so nine significant LM elements recognized by Kumar and Kumar (2015) are considered for study.

\section{Interpretive structural modeling (ISM)}

Interpretive structural modeling (ISM) approach was developed by Warfield (1974) and Sage (1977) and is employed for analyzing the correlation between various variables which influences the system under study. It helps in assigning the rank for the variables in the order with which order they affects the entire structure. The significance of ISM is to make a decision about if variables are interconnected or not. If yes then is to know through ISM that how they are connected with each other. The decision in relation to their present correlation is taken by a team having detailed understanding about the system under study. This includes discussion of ISM method and MICMAC analysis. The following are the steps involved for implementing the ISM approach: 
Step i: Identification of LM elements: Primary step in using ISM is to recognize the variables. For this study various elements of LM are considered as variables in the lean environment within the Indian industry. Following nine elements of LM are selected in preceding section.
a) Total Employee Involvement
b) Inventory reduction
c) Wastage identification
d) Continuous improvement
e) Load leveling
f) Small lot size
g) Cycle time reduction
h) Lead time reduction
i) Standardization

Step ii: Development of Structural Self-Interaction Matrix (SSIM): Relationship between LM elements is studied with the construction of SSIM matrix. Structural Self-Interaction Matrix (SSIM) is constructed for various LM elements as variables signifying the pair- wise relationship among the variables in the system. Four symbols are employed to indicate the correlation among the LM elements in the following order:

$\mathrm{V}$ - LM Element $i$ affects LM element $j$.

A - LM Element $j$ effects the LM element $i$.

$\mathrm{X}$ - LM Elements $i$ and $j$ affects each other.

$\mathrm{O}$ - LM Elements $i$ and $j$ are not related.

Table 2

Structural self-interaction matrix for LM elements

\begin{tabular}{|c|c|c|c|c|c|c|c|c|c|c|}
\hline S. No & Description of LM barrier & 1 & 2 & 3 & 4 & 5 & 6 & 7 & 8 & 9 \\
\hline 1 & Total Employee Involvement & & $\mathrm{V}$ & $\mathrm{X}$ & $\mathrm{V}$ & $\mathrm{V}$ & $\mathrm{V}$ & $\mathrm{V}$ & $\mathrm{V}$ & $\mathrm{V}$ \\
\hline 2 & Load levelling & & & $\mathrm{A}$ & A & $\mathrm{X}$ & $\mathrm{A}$ & $\mathrm{A}$ & $\mathrm{V}$ & $\mathrm{V}$ \\
\hline 3 & Continuous improvement & & & & $\mathrm{X}$ & $\mathrm{V}$ & $\mathrm{V}$ & $\mathrm{V}$ & $\mathrm{V}$ & V \\
\hline 4 & Wastage identification & & & & & $\mathrm{V}$ & $\mathrm{V}$ & $\mathrm{V}$ & $\mathrm{V}$ & $\mathrm{V}$ \\
\hline 5 & Standardization & & & & & & $\mathrm{V}$ & V & $\mathrm{X}$ & V \\
\hline 6 & Small lot size & & & & & & & A & $\mathrm{V}$ & $\mathrm{V}$ \\
\hline 7 & Cycle time reduction & & & & & & & & $\mathrm{V}$ & $\mathrm{O}$ \\
\hline 8 & Lead time reduction & & & & & & & & & A \\
\hline 9 & Inventory reduction & & & & & & & & & \\
\hline
\end{tabular}

Step iii: Development of initial reachability matrix: The Initial reachability matrix is derived from the Structural self-interaction matrix (SSIM) by replacing the V, A, X and O initials by either "0" or " 1 " based on following hypothesis:

i. If the cell $(i, j)$ has symbol "V". It is substituted by " 1 " and the corresponding cell $(j, i)$ is assigned " 0 " in initial the reachability matrix.

ii. If the cell $(i, j)$ has symbol " $A$ ". It is substituted by " 0 " and the corresponding cell $(j, i)$ is assigned " 1 " in initial the reachability matrix.

iii. If the cell $(i, j)$ has symbol " $X$ ". It is substituted by " 1 " and the corresponding cell $(j, i)$ is assigned " 1 " in initial the reachability matrix.

iv. If the cell $(i, j)$ has symbol " $O$ ". It is substituted by " 0 " and the corresponding cell( $j, i)$ is assigned " 0 " in initial the reachability matrix 
Table 3

Initial reachability matrix

\begin{tabular}{cllllllllllc}
\hline S. No & Description of LM barrier & 1 & 2 & 3 & 4 & 5 & 6 & 7 & 8 & 9 & Driving power \\
\hline 1 & Total Employee Involvement & 1 & 1 & 1 & 1 & 1 & 1 & 1 & 1 & 1 & 9 \\
2 & Load levelling & 0 & 1 & 0 & 0 & 1 & 1 & 0 & 1 & 1 & 5 \\
3 & Continuous improvement & 1 & 1 & 1 & 1 & 1 & 1 & 1 & 1 & 1 & 9 \\
4 & Wastage identification & 0 & 1 & 1 & 1 & 1 & 1 & 1 & 1 & 1 & 8 \\
5 & Standardization & 0 & 1 & 0 & 0 & 1 & 1 & 1 & 1 & 1 & 6 \\
6 & Small lot size & 0 & 1 & 0 & 0 & 0 & 1 & 0 & 1 & 1 & 4 \\
7 & Cycle time reduction & 0 & 1 & 0 & 0 & 0 & 1 & 1 & 1 & 0 & 4 \\
8 & Lead time reduction & 0 & 0 & 0 & 0 & 1 & 0 & 0 & 1 & 0 & 2 \\
9 & Inventory reduction & 0 & 0 & 0 & 0 & 0 & 0 & 0 & 1 & 1 & 2 \\
\hline & Dependence power & 2 & 7 & 3 & 3 & 6 & 7 & 5 & 9 & 7 & \\
\hline
\end{tabular}

Step iv: Level identification: Reachability matrix is used for identification of different levels for various LM elements. Reachability set and antecedent set are determined for LM elements from the reachability matrix. The element in the matrix affecting the other element are contained in reachability and antecedent set. Consequently, the intersection is achieved for these sets for every LM elements. High rank LM elements in the hierarchy of ISM model are considered as elements that are common in the intersection and reachability sets. The high ranked elements do not facilitate supplementary elements to get the level higher than their individual level. The top level of elements is recognized through this method and the same method is repeated in iterative way until level for all the elements is recognized see from Table 4 to Table 10. The final structure of the system as ISM model and diagraph are drawn on the basis of determined levels for the elements.

Table 4

$1^{\text {st }}$ Iteration of reachability matrix to estimate the rank of LM element

\begin{tabular}{ccccc}
\hline LM element & Reachability set & Antecedent set & Intersection & Level \\
\hline 1 & 123456789 & 13 & 13 & \\
2 & 25689 & 1234567 & 256 & \\
3 & 123456789 & 134 & 134 \\
4 & 23456789 & 134 & 34 \\
5 & 256789 & 123458 & 258 \\
6 & 2689 & 1234567 & 26 & \\
7 & 2678 & 13457 & 7 & \\
8 & 58 & 123456789 & 58 & I \\
9 & 89 & 1234569 & 9 & \\
\hline
\end{tabular}

Table 5

$2^{\text {nd }}$ Iteration to estimate the rank of LM element

\begin{tabular}{ccccc}
\hline LM element & Reachability set & Antecedent set & Intersection & Level \\
\hline 1 & 12345679 & 13 & 13 & \\
2 & 2569 & 1234567 & 256 & \\
3 & 12345679 & 134 & 134 & \\
4 & 2345679 & 134 & 34 & \\
5 & 25679 & 123458 & 25 & \\
6 & 269 & 1234567 & 26 & \\
7 & 267 & 13457 & 7 & \\
9 & 9 & 1234569 & 9 & II \\
\hline
\end{tabular}


Table 6

$3^{\text {rd }}$ Iteration to estimate the rank of LM element

\begin{tabular}{ccccc}
\hline LM element & Reachability set & Antecedent set & Intersection & Level \\
\hline 1 & 1234567 & 13 & 13 & 256 \\
2 & 256 & 1234567 & 134 & III \\
3 & 1234567 & 134 & 34 & \\
4 & 234567 & 134 & 25 & III \\
5 & 2567 & 123458 & 26 & 7 \\
\hline
\end{tabular}

\section{Table 7}

$4^{\text {th }}$ Iteration to estimate the rank of LM element

\begin{tabular}{ccccc}
\hline LM element & Reachability set & Antecedent set & Intersection & Level \\
\hline 1 & 13457 & 13 & 13 & \\
3 & 13457 & 134 & 134 & \\
4 & 3457 & 134 & 34 & \\
5 & 57 & 123458 & 5 & \\
7 & 7 & 13457 & 7 & IV \\
\hline
\end{tabular}

Table 8

$5^{\text {th }}$ Iteration to estimate the rank of LM element

\begin{tabular}{ccccc}
\hline LM element & Reachability set & Antecedent set & Intersection & Level \\
\hline 1 & 1345 & 13 & 13 & 134 \\
3 & 1345 & 134 & 34 & 5 \\
4 & 345 & 134 & 5 & V \\
\hline
\end{tabular}

\section{Table 9}

$6^{\text {th }}$ Iteration to estimate the rank of LM element

\begin{tabular}{ccccc}
\hline LM element & Reachability set & Antecedent set & Intersection & Level \\
\hline 1 & 134 & 13 & 13 & VII \\
3 & 134 & 134 & 134 & VI \\
4 & 34 & 134 & 34 & VI \\
\hline
\end{tabular}

Table 10

Final ranking matrix for all LM elements

\begin{tabular}{ccccc}
\hline LM element & Reachability set & Antecedent set & Intersection & Level \\
\hline 1 & 123456789 & 13 & 13 & VII \\
2 & 25689 & 1234567 & 256 & III \\
3 & 123456789 & 134 & 134 & VI \\
4 & 23456789 & 134 & 34 & VI \\
5 & 256789 & 123458 & 258 & V \\
6 & 2689 & 1234567 & 26 & III \\
7 & 2678 & 13457 & 7 & IV \\
8 & 58 & 123456789 & 58 & I \\
9 & 89 & 1234569 & 9 & II \\
\hline
\end{tabular}

\section{The MICMAC analysis}

MICMAC analysis is employed in analyzing the driving power and dependence powers for all the LM 
elements. Driving power of a LM element as a variable is achieved by adding all ones assigned for supplementary variable in the columns beside a variable in a row and dependence power is calculating by adding all ones assigned for supplementary variable in rows assigned for a variable in the column as shown in Table 3. LM elements has been categorized for their dependence power and driving power they are categorized into four group as autonomous elements, linkage elements, dependent elements and independent elements. The diagram depicting the dependence power and driving power for LM elements is shown in below

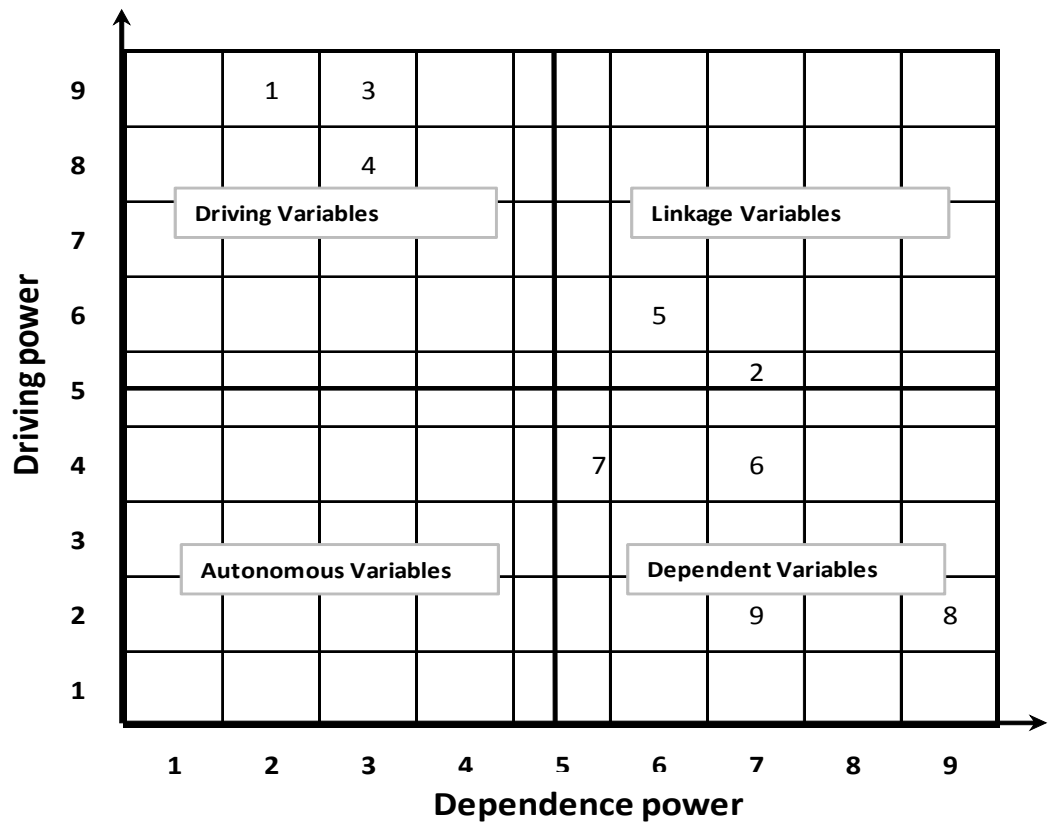

Fig. 1. Diagram showing the driving power and dependence power for LM elements

LM element no. 1 has a driving power to the tune of 9 and highest in the system and the dependence power of 2 hence it is placed at the corresponding cell. In the same manner all the LM elements are allocated the cells based on their driving power and dependence power. The intention of classification of the LM elements is to examine the dependence power and the driving power of the individual LM elements. The independent elements are those LM elements that have strong driving power but their dependence power is weak. In the given figure 1, 3 and 4 are the independent LM elements. The dependent elements are those with high dependence power but low in driving power and in this case LM variable no.8 is dependent variable. LM element no 6,9 and 7 also lies in the same segment with different order. Autonomous variable or LM element in this case are those LM elements which has low deriving and low dependence power. The autonomous elements remains comparatively disengaged from the organization and they may not have any impact on other LM elements. In the studied no LM element is autonomous variable. The linkage variable segment has strong driving and dependence power and the LM elements lying into this segment is element no 5 and 2 . Whatever action is taken for these LM elements will affect the supplementary LM elements.

\section{Construction of digraph and ISM model}

The interpretive structural model (ISM) is constructed base on initial reachability matrix depicted in Table 3. The present relation among various LM elements is indicated by drawing an arrow from LM element $\mathrm{i}$ to LM element $\mathrm{j}$. Construction of the graph is known as initial directional graph. The final ISM model is obtained from initial directional graph by subsuming the LM elements names in place of the LM element numbers. 


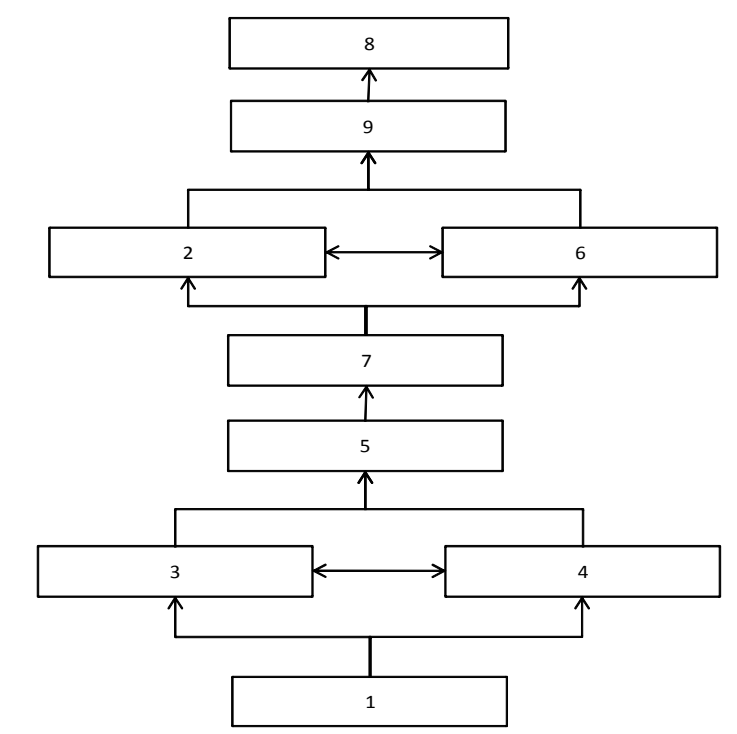

Fig. 2. The digraph illustrating the relationship between the LM elements

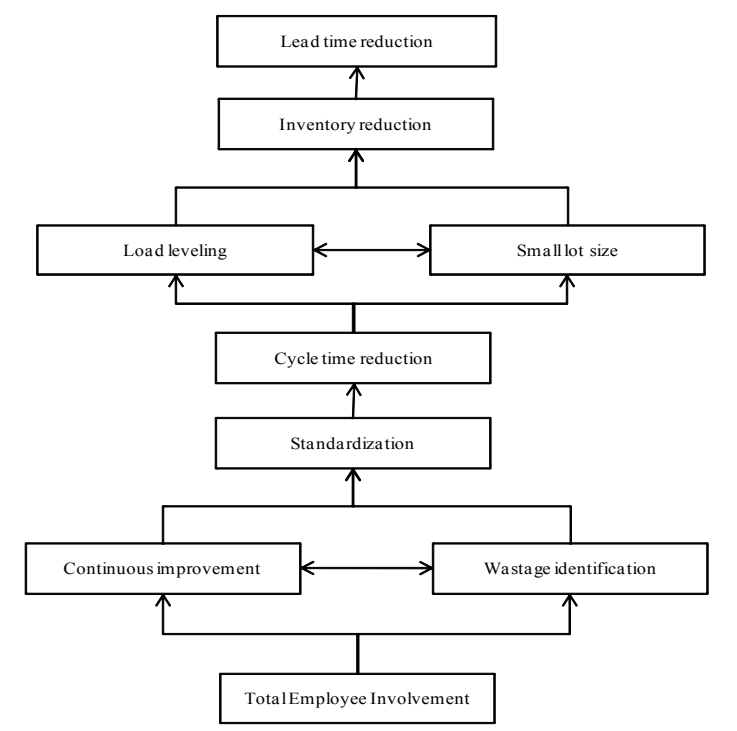

Fig. 3. Final ISM based model for LM elements

\section{Results}

The ISM model shown in Fig. 3 reveals the position of all the significant LM elements regarding based on the importance of their role in the implementation of LM. The directional arrows indicate that a particular element is dictated by other one or is dictating to others as shown in the diagram. The positioning of elements is based on their ranking in context with their driving power and dependence power. Element having more driving power may impact the element with low value of driving power. In the studied case elements of lean manufacturing in Indian context are analyzed and it is evident from interpretive structural model that lead time reduction is the top ranked LM element. This can be achieved by achieving inventory reduction which is supported by load leveling and introducing smaller lot sizes, reducing cycle time and with standardization of processes. Wastage identification and continuous improvement helps in achieving above mentioned elements with the support of total employee's involvement.

\section{Conclusions}

Successful implementation of LM can be ensured by knowing the LM elements and their level. Total employee's involvement, continuous improvement and wastage identification are independent elements LM because of low level of dependence and high driving power among all the LM elements and so it is placed at the down most level in ISM model. The lead time reduction is placed at the highest level being a dependent LM element because it has high dependence power and comparability low driving power. It may not have impact on other element at its own but is dependent on many elements to get achieved. There is no autonomous element indicates that each element has its active role in LM implementation. Linkage elements are load leveling and standardization of processes. The understanding about relationship and levels of different LM elements is important for Indian industry to make step forward in LM implementation. In Fig. 3 it is indicated that companies must focus on engaging their employee's to work for continuous improvement and wastage identification so that lean implementation can be made easy in the Indian industry.

Ranking of various LM elements with diagraph and development of ISM model based on their ranking has significant relevance for researchers and practiceners. The study of LM elements and knowing their status can be helpful in knowing the significant elements of LM for the Indian industries. The Indian industry should identify the priority of the area for improvement in order to enhance the impact of elements in LM and consequently improve upon their competitiveness. 


\section{References}

Ahuja, I. P. S., \& Khamba, J. S. (2008). An evaluation of TPM initiatives in Indian industry for enhanced manufacturing performance. International Journal of Quality \& Reliability Management, 25(2), 147-172.

Amasaka, K. (2002). "New JIT": A new management technology principle at Toyota. International Journal of Production Economics, 80(2), 135-144.

Anand, G., \& Kodali, R. (2008). Selection of lean manufacturing systems using the PROMETHEE. Journal of Modelling in Management, 3(1), 40-70.

Antony, J., \& Desai, D. A. (2009). Assessing the status of Six Sigma implementation in the Indian industry: results from an exploratory empirical study. Management Research News, 32(5), 413-423.

Attri, R., Dev, N., \& Sharma, V. (2013). Interpretive structural modelling (ISM) approach: an overview. Research Journal of Management Sciences, 2(2), 3-8.

Bakås, O., Govaert, T., \& Van Landeghem, H. (2011). Challenges and success factors for implementation of lean manufacturing in European SMES. In 13th International conference on the Modern Information Technology in the Innovation Processes of the Industrial Enterprise (MITIP 2011) (Vol. 1). Tapir Academic Press.

Chowdary, B. V., \& George, D. (2011). Improvement of manufacturing operations at a pharmaceutical company: a lean manufacturing approach. Journal of Manufacturing Technology Management, 23(1), 56-75.

Deif, A. (2012). Assessing lean systems using variability mapping. Procedia CIRP, 3, 2-7.

Ferdousi, F. (2009). An investigation of manufacturing performance improvement through lean production: A study on Bangladeshi garment firms. International Journal of Business and Management, 4(9), 106-116.

Gorvett, R., \& Liu, N. (2007, June). Using interpretive structural modeling to identify and quantify interactive risks. In Orlando-USA: ASTIN Colloquium.

Joshi, M. R. R., \& Naik, G. R. (2012, March). Process improvement by using value stream mapping:A case study in small scale industry. International Journal of Engineering Research and Technology, 1(5), 1-10.

Khadse, P. B., Sarode, A. D., \& Wasu, R. (2013). Lean Manufacturing in Indian Industries A Review. International Journal of Latest Trends in Engineering and Technology, 3(1), 175-181.

Kumar, R., \& Kumar, V. (2012). Lean Manufacturing System: An overview. In Proceedings of the National Conference on Trends and Advances in Mechanical Engineering, YMCA. University of Science \& Technology, Faridabad, Haryana (pp. 742-747).

Kumar, R., \& Kumar, V. (2014). Barriers in implementation of lean manufacturing system in Indian industry: A survey. International Journal of Latest Trends in Engineering and Technology, 4(2), 243-251.

Kumar, R., \& Kumar, V. (2015). Lean manufacturing in Indian context: A survey. Management Science Letters, 5(4), 321-330.

Kumar, V., Garg, D., \& Mehta, N. P. (2004). JIT practices in Indian context: A survey. Journal of Scientific and Industrial Research, 63(8), 655-662.

Kumar, V. (2010). JIT based quality management: concepts and implications in Indian context. International Journal of Engineering Science and Technology, 2(1), 40-50.

Kumar, N., Kumar, S., Haleem, A., \& Gahlot, P. (2013). Implementing lean manufacturing system: ISM approach. Journal of Industrial Engineering and Management, 6(4), 996-1012.

Luthra, S., Kumar, V., Kumar, S., \& Haleem, A. (2011). Barriers to implement green supply chain management in automobile industry using interpretive structural modeling technique: an Indian perspective. Journal of Industrial Engineering and Management, 4(2), 231-257.

Mandal, A., \& Deshmukh, S. G. (1994). Vendor selection using interpretive structural modelling (ISM). International Journal of Operations \& Production Management, 14(6), 52-59. 
Maroofi, F. (2013). Total Productive Maintenance for modeling the enablers in the performing of ISM access. International Research Journal of Applied and Basic Sciences, 6(8), 1161-1174.

Narain, R., Yadav, R. C., \& Antony, J. (2004). Productivity gains from flexible manufacturing: Experiences from India. International Journal of Productivity and Performance Management, 53(2), 109-128.

Nordin, N., Deros, B. M., \& Wahab, D. A. (2010). A survey on lean manufacturing implementation in Malaysian automotive industry. International Journal of Innovation, Management and Technology, 1(4), 374-380.

Oehmen, J., Oppenheim, B. W., Secor, D., Norman, E., Rebentisch, E., Sopko, J. A., ... \& Driessnack, J. (2012). The guide to lean enablers for managing engineering programs. MIT PMI INCOSE Community of Practice on Lean in Program Management.

Rahman, S., Laosirihongthong, T., \& Sohal, A. S. (2010). Impact of lean strategy on operational performance: a study of Thai manufacturing companies. Journal of Manufacturing Technology Management, 21(7), 839-852.

Raj, T., Shankar, R., \& Suhaib, M. (2008). An ISM approach for modelling the enablers of flexible manufacturing system: the case for India. International Journal of Production Research, 46(24), 6883-6912.

Saraswat, P., Sain, M. K., \& Kumar, D. (2014). A review on waste reduction through value stream mapping analysis. International Journal of Research, 1(6), 200-207.

Shah, R., \& Ward, P. T. (2003). Lean manufacturing: context, practice bundles, and performance. Journal of Operations Management, 21(2), 129-149.

Shah, R., \& Ward, P. T. (2007). Defining and developing measures of lean production. Journal of Operations Management, 25(4), 785-805.

Shahabadkar, P. (2012). Deployment of Interpretive Structural Modelling Methodology in Supply Chain Management-An overview. International Journal of Industrial Engineering \& Production Research, 23(3), 195-205.

Singh, B., Garg, S. K., \& Sharma, S. K. (2009). Lean can be a survival strategy during recessionary times. International Journal of Productivity and Performance Management, 58(8), 803-808.

Singh, B., Garg, S. K., Sharma, S. K., \& Grewal, C. (2010). Lean implementation and its benefits to production industry. International Journal of Lean Six Sigma, 1(2), 157-168.

Singh, T., \& Dubey, R. (2013). Soft TQM practices in Indian cement industry-an empirical study. International Journal of Productivity and Quality Management, 11(1), 1-28.

Singh, M. D., \& Kant, R. (2008). Knowledge management barriers: An interpretive structural modeling approach. International Journal of Management Science and Engineering Management, 3(2), 141150.

Singh, H., \& Khamba, J. S. (2011). An Interpretive Structural Modelling (ISM) Approach for advanced manufacturing technologies (AMTs) utilisation barriers. International Journal of Mechatronics and Manufacturing Systems, 4(1), 35-48.

Taj, S., \& Morosan, C. (2011). The impact of lean operations on the Chinese manufacturing performance. Journal of Manufacturing Technology Management, 22(2), 223-240.

Upadhye, N., Deshmukh, S. G., \& Garg, S. (2010). Lean manufacturing system for medium size manufacturing enterprises: an Indian case. International Journal of Management Science and Engineering Management, 5(5), 362-375.

Womack, J. P., Jones, D. T., \& Roos, D. (2008). The machine that changed the world. Simon and Schuster.

Wong, Y. C., Wong, K. Y., \& Ali, A. (2009). A study on lean manufacturing implementation in the Malaysian electrical and electronics industry. European Journal of Scientific Research, 38(4), 521535.

Yang P., \& Yu Y. (2010). The barriers to SMEs' implementation of lean production and countermeasures - based on SMS in Wenzhou. International Journal of Innovation, Management and Technology, 1(2), 220-225. 